\title{
ANALYSIS OF WATERPROOFING DEFECTS AND TECHNOLOGY DEVELOPMENT FOR CAR PARKING ROOFS: LITHUANIAN CASE
}

\author{
Leonas Ustinovichius ${ }^{1}$, Romas Rasiulis ${ }^{2}$, Česlovas Ignatavičius ${ }^{3}$, TatjanaVilutiené ${ }^{4}$ \\ Vilnius Gediminas Technical University, Sauletekio al. 11, LT-10223 Vilnius, Lithuania \\ E-mails: ${ }^{1}$ leonas.ustinovicius@vgtu.lt; ${ }^{2}$ romarasi@gmail.com (corresponding author); \\ ${ }^{3}$ IC@ takas.lt; ${ }^{4}$ tatjana.vilutiene@vgtu.lt \\ Received 07 Feb. 2012; accepted 26 Apr. 2012
}

\begin{abstract}
This work presents the analysis of installation options of exploitable car park roofs offered by the designers, material manufacturers and suppliers and introduces the Lithuanian legislation with the requirements for this type of roofing. Reasons of the most frequently occurring defects have been examined and several options for correcting defects have been provided. The most cost-effective option for correcting the defect in question has been chosen. Practical measures for increasing the reliability of exploitable car park roofs have been proposed. The analysis has shown that at a minimum slope reliability of the exploitable roof coated with roller heat-welded materials is not guaranteed. The authors propose to tighten the requirements on car park roofing.
\end{abstract}

Keywords: waterproofing, roof slope, exploitable roof, flat roof.

\section{Introduction}

Since congestion of vehicles in cities is constantly increasing, car parking problem is becoming more and more acute. Due to land scarcity and continual price increases parking lots turn into a multi-storey or underground structures (Milosavljevic et al. 2010). Therefore it is natural that attempts are made to exploit roofs of such buildings - they are becoming an additional space to keep vehicles or can be installed as a pedestrian zone. Strict requirements are applied for this type of roofing. Roof coating shall be watertight in order to prevent the roof structural elements from corrosion and erosion, be able to bear vehicle loads (Medeliene, Žiogas 2010), the roof spaces in use must be safe for traffic participants and, of course, be aesthetically attractive. Similar problems may arise while exploiting green roofs, which can be installed for both the aesthetic and economic reasons.

Currently, the industry can supply a wide range of different materials for waterproofing of flat roofs (Oba, Hugener 1995; Ogle et al. 2004; Baskaran et al. 2008, 2009; Baskaran, Molleti 2009). Their proper use may extend the durability of the roof to 30 years and more. But actually, after the start of exploitation of flat roofs with car parks installed on top, experts have been receiving many complaints about lack of credibility of such type of roofing. As it is known, the basic conditions for ensuring the reliability of the roof are the right design solution, the use of quality materials and rigorous compliance to technological requirements on roof installation.

Roof is the top covering part of the building, protecting its interior from atmospheric effects (STR 2.05.02:2008 2008). Walter et al. (2005) has classified the most common defect types and causes. Although this work deals with exploitable roofs designed for car parks, but similar problems may arise when exploiting green roofs, which can be installed for both the aesthetic and economic purposes (Wong et al. 2003; Ismail et al. 2010). Gränne et al. (2003) tested the wind load resistance of joints between roofing felt and sheet metal and found that peeling is the dominating process in the failure of joints during wind load.

Based on extensive research, it was found that the greatest damage to structures has been caused by violations related to defective waterproofing. For example, tests performed in Sweden (Gränne, Björk 2000) show that it is possible to obtain joints with sufficient strength using the contractors ordinary welding procedures. In Norway, which is famous for high level of labour culture, the building defects related to waterproofing violations represent $41 \%$ of all defects (Lisø et al. 2005). It is likely that in Lithuania this percentage is even higher.

Currently, reduction of energy consumption is becoming a topical problem, which can only be achieved by proper installation of insulation layer, using appropriate materials (Rudbeck 2002). One of the most widely used thermo insulation building materials is expanded polystyrene. According to Vaitkus et al. (2006), exploitation of expanded polystyrene in most cases is related to compression deformations. Properties of such materials are directly dependent on the structure and shape of a pore or granule.

The most serious problem of glued roller cover materials for roofs is insufficient reliability of seams between the strips of glued membrane. Karablikovas (2007) was focused on the mechanism of seams formation and the determination of seams quality parameters - the 
thickness of seam, the strength and unglued area of seam. Research indicates that using of bituminous heat-welded polymeric substances for installation of rolled flat roofs increased their durability. The research of this problem focused on the mechanism of seams formation and the impact of gluing technology on seams quality parameters - strength, thickness and emergence of unglued areas in the seam. The final seam thickness is regarded as an additional indicator and the research-based importance of this indicator has been presented. The dependence of adhesion strength on heating duration of melted surfaces has been proven experimentally. The research shows that the maximum strength of seams does not exceed $15-20 \%$ of the rolled cover material strength and can not be increased by applying the existing roof gluing technology. A series of practical measures for increasing the reliability of flat roofs bituminous membranes have been proposed. Later Karablikovas and Vilutienè (2010) made an analysis of the dependence of seam strength on heating duration of melted surfaces and provided the suggestions for glued roller roofing technologies. The dependence has been determined experimentally. The analysis had shown that the heating regime not ensures the necessary gluing level of membrane layers.

The aim of the Oba et al. (1996) study was to understand how the T-peel strength of heat-welded seams in polymer-modified bituminous roofing membranes depends on the welding method and on the material properties. It was concluded that the choice of welding speed and pressure weight for the optimum design of welding machine should make reference to the thermal properties, such as specific heat, and to the rheological properties, such as viscosity.

Fajkos (2007) tests had shown that temperature affects the overlap character of seams. Nil and Ertan (2004) argues that at the very wall waterproofing is exposed to the highest pressure. Under these conditions, the stresses caused in the coating reduce the thickness of the membrane, leading to an increased probability of water and vapour permeability. This effect is also relevant to bituminous coatings, as high compressive pressure can cause leakage through the seams. It has been estimated that the maximum strength of roof seams is 5-6 times smaller than the strength of roller material (Karablikovas 2007).

The satisfactory performance of a membrane waterproofing system, during its useful life, relies solely on the permeability of the waterproofing membrane, when construction and workmanship are correctly implemented. In field conditions, the membranes are subjected to various stresses, such as those brought about by building loads and lateral soil pressure that may strain the membrane, particularly in deep basements, and adversely affect its permeability. Nil and Ertan (2004) proposed a new performance-based laboratory test method to assess the vapour and water permeability of strained waterproofing membranes under hydrostatic pressure. The novelty of the method is that for a given basement configuration (height and depth), the effects of strain arising from tensile stress and compressive pressures acting on the membrane are simulated on the test specimen and the vapour and water permeability is measured in laboratory conditions. The test results confirmed that at some strain levels that simulate field conditions, to which membranes can be subjected, the strained membranes transmitted vapour under hydrostatic pressure. The tests also revealed that the test apparatus was effective in measuring the vapour and water permeability of the specimens under hydrostatic pressure (Nil, Ertan 2004).

Performance of elastomeric waterproofing membrane depends not only on the material properties, but also on the quality of the installing equipment. Currently, among the products on sale there are cold, liquid, spreadable, self-adhesive elastomers, which differ in chemical composition and application methods. Application problems can emerge due to changes in atmospheric conditions, quality of work and surface preparation. Mailvaganam and Collins (2004) examined the interaction of quality of five elastomeric membranes with the quality of surface preparation. The results show that due to the poor quality of work performed and lack of control the final product is unstable.

Atkinson (2002) analyzed the impact of the managerial staff on emergence of defects. Research results confirmed that most of the defects occur due to insufficient performance of managerial staff, but this can also be attributed to random chain of events. Quite often wrong solutions of the managerial staff result in errors in subsequent work processes which lead to making incorrect conclusions followed by inappropriate actions. The study also proposes a conceptual model of the nature of an error in construction projects and shows that the defects result from the impact of management decisions thus, when investigating the causes of incidents organizations must be assessed in an integrated way.

Mailvaganam and Collins (1999) identified three main factors affecting the work of elastomeric membranes on the car park roofing: quality of installation, quality of ground preparation and environmental conditions. It is also important to comply with the manufacturer's instructions while carrying out the work.

The aim of this work is to identify causes of defects of the test car park, offer a rational option of failure correction and measures for installation of exploitable roofs in the future in order to increase their reliability.

\section{Analysis of modern roofing construction}

Currently, depending on the destination, flat roofs are made as non-exploitable and exploitable, latter furnished with terraces, flower gardens and swimming pools. Constructively roofs can be thermo insulated and noninsulated, ventilated and non-ventilated. Insulated roofs according to thermal insulation placed in the roof structure can be divided into direct or reverse. Despite this diversity, the main elements of flat roofs remain the same: supporting structure; vapour barrier; heat insulation with ventilated air space or without it; levelling layer; high-quality waterproofing coating that must remain leakproof at long-term, withstand the extreme loads and serve as protective layer. 


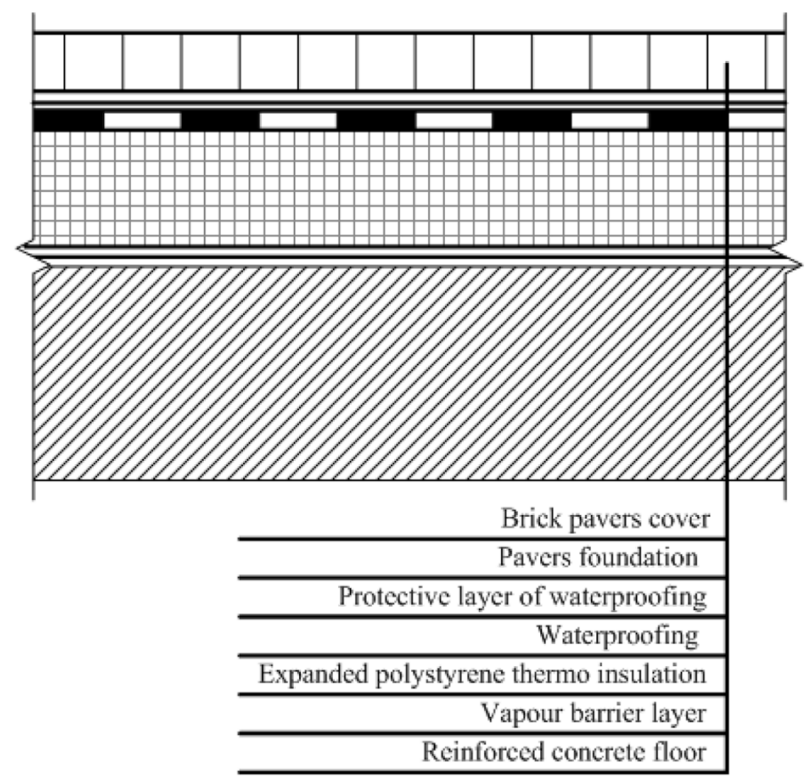

Fig. 1. Installation option of the direct exploitable roof



Fig. 2. Installation option of the reverse exploitable roof

Installation Options of Exploitable Roofing. The figures below presents the installation options of the exploitable roof: first - the direct exploitable roof, when the waterproofing layer is installed over the thermo insulation layer (Fig. 1); and second - the reverse exploitable roof, when waterproofing layer is installed under the thermo insulating layer (Fig. 2).

Types of waterproofing. The figures below present different classifications of waterproofing coatings (Gajauskas 2004): first - the classification according to the origin (Fig. 3), and second - according to the possible ways of fastening of waterproofing materials (Fig. 4). First classification ("by origin") divides the waterproofing coatings into three main groups, i.e. roller roof coatings, membrane coatings and mastics. Waterproofing coatings could be fastened by different ways: glued with special glues, mastics, by hot air; poured, sprayed, fastened mechanically, ballast-loaded and, finally, heat-welded.

\section{Constructing roof slope}

Reinforced concrete slabs are the basis of roofing. Reinforced concrete slabs must withstand the static and dynamic loads. Good water drainage is required in order to protect reinforced concrete slabs, thermo insulation, structures below and other assets from the adverse effect of water.

Reinforced concrete slabs are usually made of a monolithic and prefabricated reinforced concrete. Reinforced concrete slabs are calculated for the entire operational period, so the waterproofing coating together with the design of roof slope should ensure the operational longevity of structure.

The flat roofs are sensitive to cracking and leakage; therefore flat roofs must be designed so that water can drain off quickly from the roof surface. No exceptions can be allowed in designing a roof without slopes. One can often see water accumulation or swamps on the old roofs. This is due to the minor slope, therefore water causes additional threats and there is a risk that in the weakest areas water will penetrate and seep into the roof structure.

Typically the slope is achieved in the following ways:

- by installing bearing structures with a slope;

- with the help of levelling layer;

- using thermo insulation materials of a variable thickness.

Thermo insulation materials of a variable thickness are not used in roofs of a complex surface.

Minimum and maximum values of roof slope are regulated by the Construction Technical Regulations. The minimum allowable slope or grade of exploitable flat roofs in Lithuania is $0.7^{\circ}(1.25 \%)$ (STR 2.05.02:2008 2008). To achieve quick water runoff from such roof, the designer must estimate the possible inaccuracies and deformations during the installation and installer must avoid the fitting errors. If latter occur, slope decreases and properties of flat roof become worse (Fig. 5).

After increasing the slope twice, theoretically it becomes $1.4^{\circ}(2.5 \%)$, but in practice due to a possible sags the slope becomes at an average around $0.7^{\circ}(1.25 \%)$ (Fig. 6).

When choosing a minimum slope after the evaluation of possible deflections, it is necessary to pay attention to sags in the roof structure which can have either a positive (Fig. 7) or negative impact on water runoff (Fig. 8).

After the installation of roof drain in the mid-span, the sag improves water runoff (Fig. 7). However, in most cases, roof drains are installed near walls or columns, and then the sag usually worsens the runoff (Fig. 8). When choosing the roof slope, it is necessary to take into account the following conditions:

- when forming a slope with a levelling layer, the construction sag is filled with the levelling substance, so the slope becomes constant; 


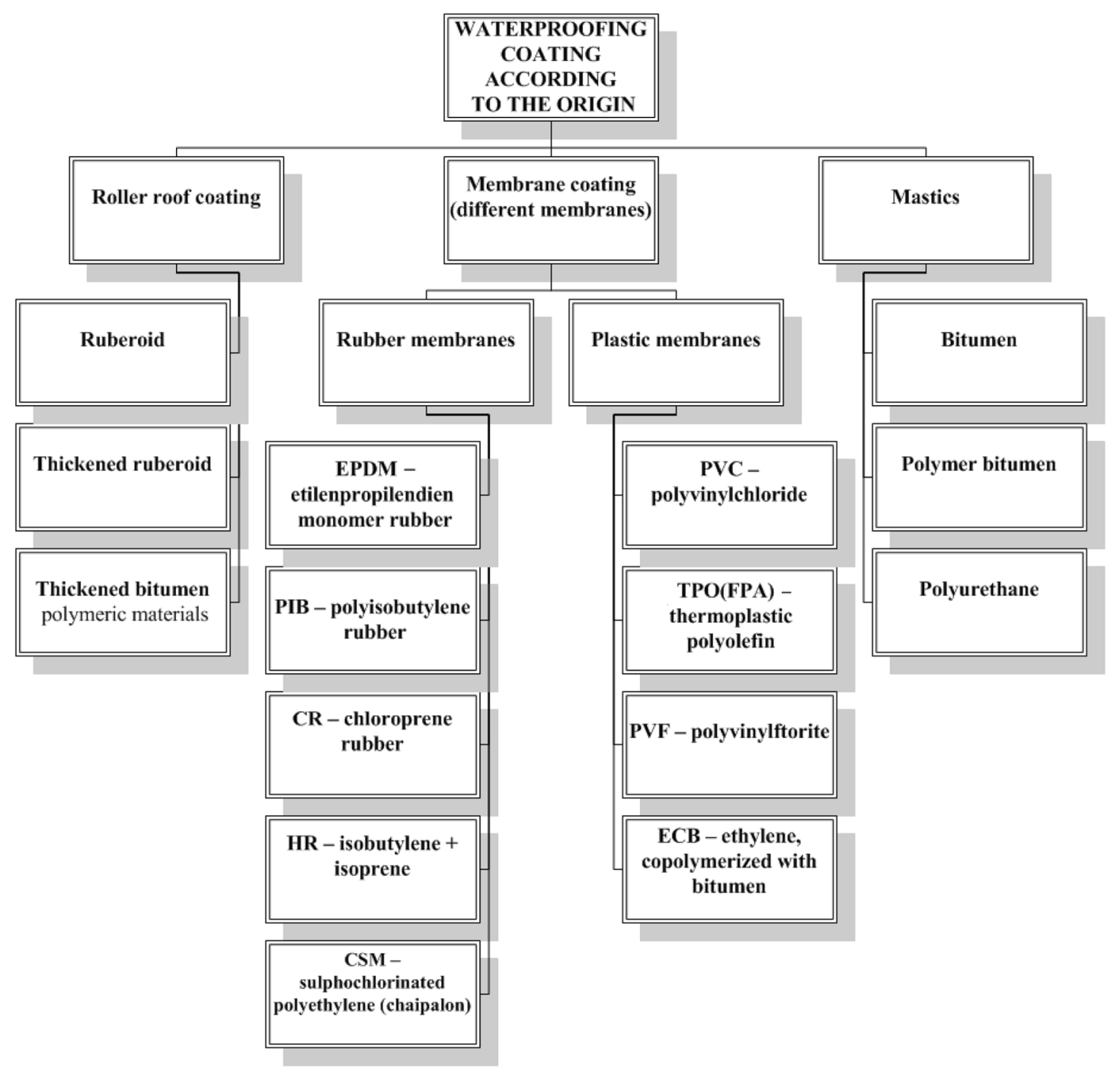

Fig. 3. Classification of waterproofing coatings by origin



Fig. 4. Classification of waterproofing coatings by way of fastening 


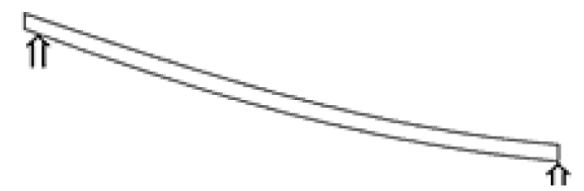

Fig. 5. A scheme showing a reduced slope due to fitting errors (slope 1:80)

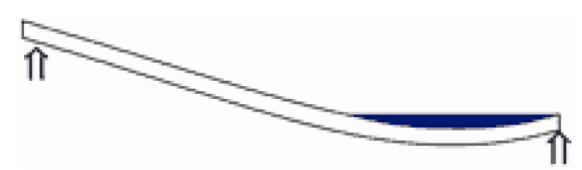

Fig. 6. A scheme showing the formation of swamps due to fitting errors (slope 1:40)

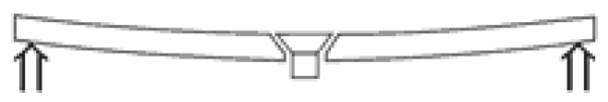

Fig. 7. A scheme showing how the sagging in the roof improves the runoff

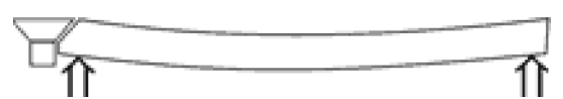

Fig. 8. A scheme illustrating how the sagging in the roof worsens the runoff

- at the junction of two slopes of different directions a confluence may arise and its effectiveness gets smaller than that of the basic area.

Let us examine the situation where the designed marginal slopes of the roof base are $0.7^{\circ}(1.25 \%)$. The designers often do it because of large parking areas and restricted possibilities to thicken the roof structure. In this case, the slope of the roof at the confluence will be only $0.5^{\circ}(0.88 \%)$ (Fig. 9). However, this doesn't comply with requirements (STR 2.05.02:2008 2008).

Layout possibilities for rain water gutters, installed inside and generally located near the main supports, as well as for roof drains, are often limited. Despite that fact, roof drains should be installed in way to ensure the adequate slopes of the roof surface. The slopes in such case should ensure the water runoff both in perpendicular and diagonal directions in respect of the roof sides (Fig. 9).



Fig. 9. Scheme of junction of roof slopes in place of rain water gutters

Particular attention should be given to the installation of water drainage layer. If the roof slope is correct, but water can not run off freely, sooner or later will appear the problem of water leakage.

There are three options for installing roof flashing: different mastics, membrane coatings and bituminous polymeric roller heat-welded or glued by a variety of roofing mastics. This article analyses only roller roofing most often used for flat roofs.

The main criteria that determine the quality of roof installation are as follows:

- exploitable flat roof slope must be at least $0.7^{\circ}$ and not more than $7^{\circ}$;

- for roofs with a slope of $0.7^{\circ}$ to $1.4^{\circ}$, the specially designed construction products and structural solutions according to the manufacturer's recommendations on installation of waterproofing cover have to be used;

- flat roof slope to the roof drain must be at least 1.4 (STR 1.05.06:2010 2010).

For the analysis of slope installation efficiency, a roof of $10 \times 10$ meters in size, whose central part is equipped with a water drain, has been chosen. The main gradient to the drain of the analyzed roof makes $2.5 \%$, the roof cover is not specifically designed for small gradients. It is assumed that the maximum roof seam strength is 5-6 times lower than the roller material strength (Karablikovas 2007). Let's analyze three possible options for formation of roof slopes with the drain in the centre (Fig. 10).

A case showed in Fig. 10a, when the roof is divided by two diagonals into four zones of triangular shape and water runoff is evenly directed to the same drain has been examined and presented Fig. 11. Suppose that the slope is

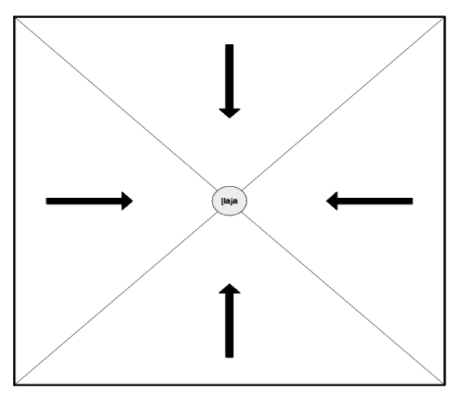

a)

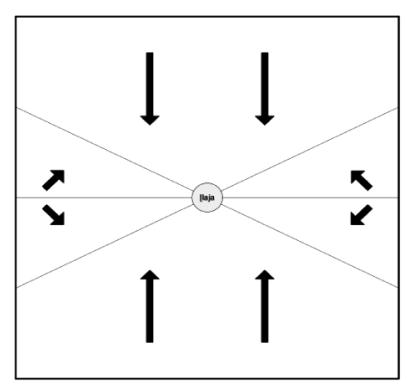

b)

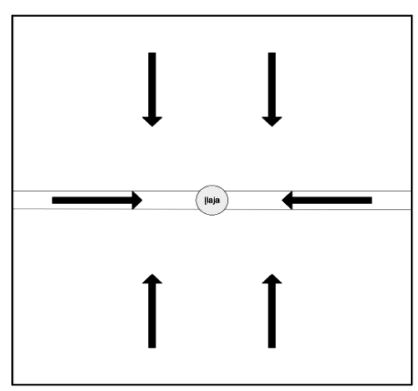

c)

Fig. 10. Possible options for formation of the roof slopes: a) all the same slopes; b) composite slopes; c) confluence in the middle 


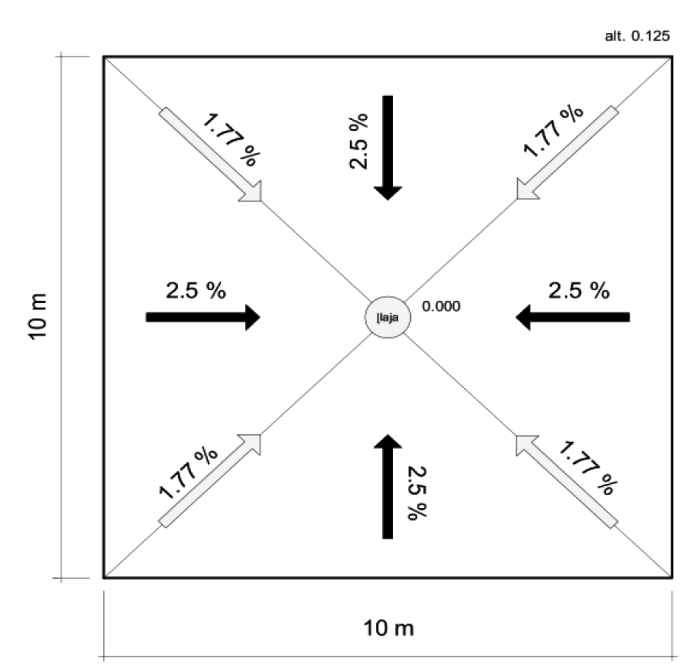

Fig. 11. The roof slopes model

$2.5 \%$ (black arrow), roof dimensions are $10 \times 10 \mathrm{~m}$, the drain is at 0.000 (zero) altitude. The present research does not take into account that within the radius of $0.5 \mathrm{~m}$ from the centre of the vertical drain roof surface must have at least $6^{\circ}$ slope to the roof drain and the altitude of the edge must be 0.125 (STR 2.05.02:2008 2008). Then the slope of the roof at the intersection of roof zones is only $1.77 \%$ (white arrow). This type of roof slope is only possible when using construction products and structural solutions specially designed for such roof slopes.

When designing flat roofs designers should consider the fact that the most commonly used type of welding devices in Lithuania are gas burners, but they can not adjust to the welding speed or clamping force, therefore it can be argued that the heat-welding of the roller cover is not a sufficiently controlled process. The only way to ensure the control is a streak of molten bitumen mass in a formed seam. The earlier researches (Karablikovas 2007) found that the strength of seams is mainly poor; therefore the fact that heat-welded roller roof covers can be used for exploitable roofs becomes questionable. There is a substantial risk that a roof with such a low gradient can start to leak due to the complicated water runoff and water accumulation at intersections.

A case showed in Fig. 10b has been examined and presented in Fig. 12. Under the same initial conditions it is not possible to raise all edges of the roof to the proper altitude (0.125), but the required slope of the roof zones $(2.5 \%)$ is maintaining (Fig. 12). In this scheme the slope at the intersection of the zones is only $1.1 \%$ (white arrow), which does not comply with requirements (STR 2.05.02:2008 2008).

In areas were the lack of the necessary degree of roof slope appear an additional waterproofing layer is required, but even this measure can not provide the full tightness of the roof against water.

When designing roofs the marginal slopes should be excluded and slopes of roof zones' intersections should be evaluated strictly (Gajauskas 2004). Fig. 13 provides the theoretical scheme of the roof, which has already met all the minimum requirements of construction technical regulations, here the slope at the intersections of roof zones

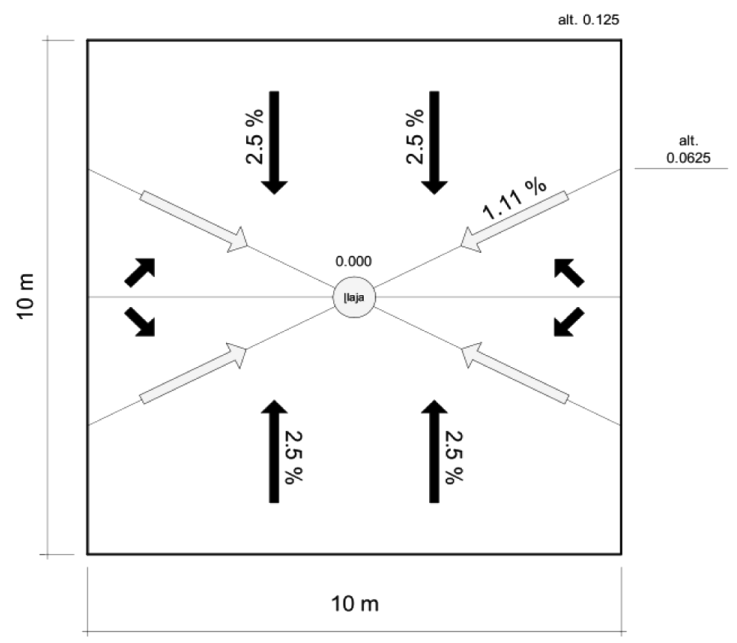

Fig. 12. Roof slope model, when the height of one or two opposite edges of the roof is limited

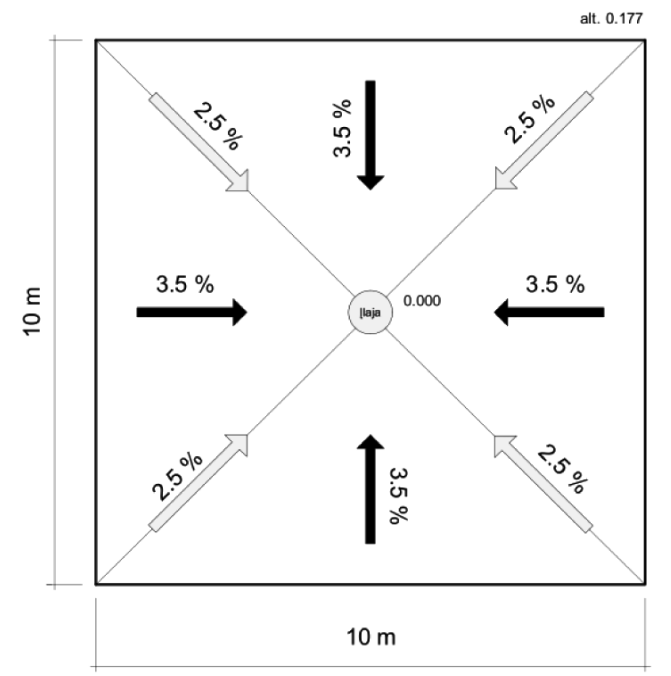

Fig. 13. The model of roof slopes and the slope size, which meets all the minimum (STR 2.05.02:2008 2008) requirements

is $2.5 \%$ (white arrows). It is recommended to start designing the roof from the intersections and only then to select the slope for other zones of the future roof.

The presented model suggests the roof slopes where the gradient of the main zones has to be $3.54 \%$, but the simulation has been adopted in ideal conditions. The possibilities of deviations in building structures (flooring, levelling layer or gradient formation) during construction and deformations of the building during its exploitation were not taken into account. Water drainage layer ("honeycomb" type or other) has also been underestimated, because the waterproofing layer of exploitable roofs is inside the roof structure. The present analysis indicates that currently the slopes in designed main roof zones are not sufficient. It is proposed to pay a special attention to the formation of slope at the intersections of roof zones when designing roofs, and in particular the exploitable ones. After assessment of poor durability of the roller heat-welded cover seams, it is recommended not to use them in exploitable roofs, but rather replace them with the membrane coatings or the similar. 


\section{Defects analysis of a car park in Vilnius}

While carrying out the analysis of defects in waterproofing, a car park building located in Vilnius, which has all the characteristic features and consequences resulting from violation of waterproofing, was studied. It was not determined if the construction work in the analyzed object was carried out in accordance with the technical requirements of the project, because unfortunately, it was not possible to find the description and installation requirements of the car park roofing layers. The surface layer of the underground parking has been covered with scotch blocks and pavement tiles.

The survey showed that actually the car park roofing has been accomplished according to the scheme shown in Fig. 14.

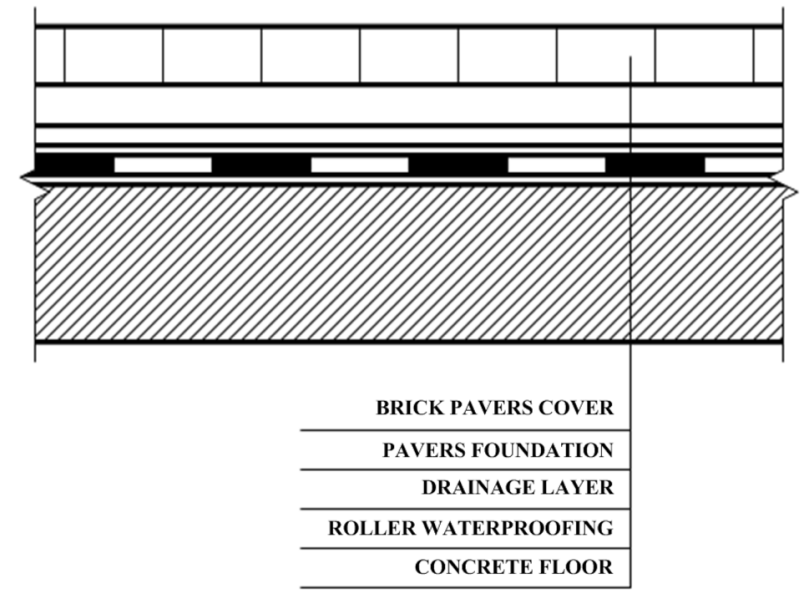

Fig. 14. Section of car park roofing

The inspection revealed that:

- there is water penetration at transoms in the car park;

- moisture penetrates through the walls of car park;

- patches of moisture penetration was observed through the floors of car park;

- there is penetration of water at the junction between the wall and floor;

- there is no flashing (weatherproofing) on the outside of the building at the basement level;

- the outer walls of the car park are not hydro insulated below the zero level.

The inspection revealed that the outer moisture gets into the basement premises of the car park. Moisture leakage causes damages to the building structures, equipment as well as to the property inside it. During the research analysis on moisture presence in the car park was carried out. Internal car park general indoor measurements were performed, the following parameters were registered:

- internal temperature: $+19.62{ }^{\circ} \mathrm{C}$;

- water concentration in air: $9.3\left(\mathrm{~g} / \mathrm{m}^{3}\right)$;

- the average relative air humidity: $66.0 \%$;

- dew point temperature: $+13.1{ }^{\circ} \mathrm{C}$.

Humidity measurements of car park construction up to 4 inches deep and thermo visual analysis of individual sites were performed.
It was find that water penetrates into the building structures due to an insufficient slope directing water from the car park roof, improper installation of exploitable roofing, absence of the draining layer. Since the easiest way for water to get inside is through the junctions/intersections of the building structures, first of all water penetration appears in these places (Fig. 15). Considering the above findings it is concluded that the construction work on installation of the car park does not meet the normative quality requirements.

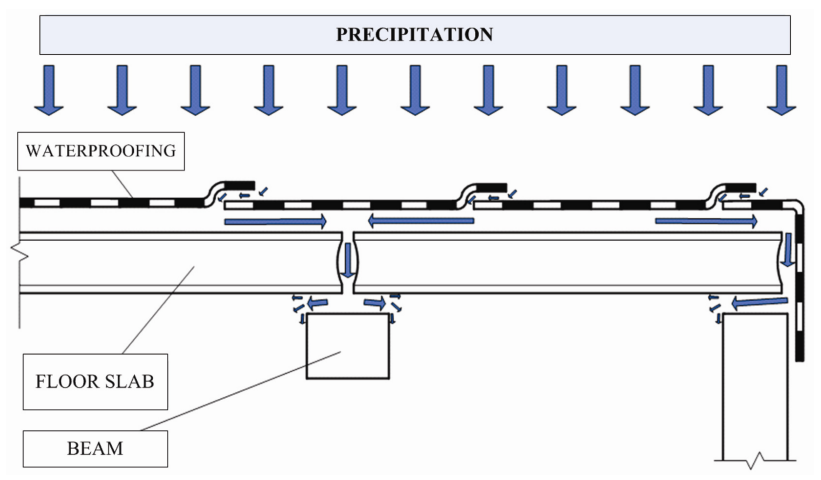

Fig. 15. Scheme of moisture entering the car park

\section{Alternatives for recovery of waterproofing layer of car park}

The study showed that the object under analysis lacks the slope formation layer beneath the waterproofing layer. This does not comply with the requirements of STR 2.05.02:2008 (2008) clause 35.2. According to the requirements an additional roof waterproofing layer and a layer designed for draining the flashing water are mandatory, but actually only one roller cover layer has been installed. The object under study has not been equipped with water draining layer and additional waterproofing layer. One waterproofing layer can not ensure watertightness due to unreliable seams of the roller cover. The research (Karablikovas 2007) shows that possibilities of increasing the adhesion strength of roller cover stripes by prolonging the heating time are limited and insufficient. To ensure the reliability of roofing from heat-welded materials it is proposed to tighten the requirements on the roof construction.

Therefore, to prevent water leakage in the future, additional waterproofing layer must be installed for the elimination of the defects under this study.

The study determined that the car park walls do not have vertical insulation from the outside, which results in water permeability of the mentioned walls.

After the assessment of waterproofing defects and their extent at the car park, two alternatives for reconstruction of waterproofing layer have been offered.

Alternative $A_{1}$. An efficient and fast way to restore the waterproofing layer is to use resilient flashing mastic. Polyurethane waterproofing material with quartz sand filler is specifically designed to protect roadways with high vehicle loads against water, salt, oil and abrasion. The flashing mastic in use must be resistant to mechani$\mathrm{cal}$, chemical and thermal effects. It is used to form upper 
layers of waterproofing. The flashing mastic allows reaching hardly accessible, complex assemblies. It fills in all major and minor surface cracks. It has good adhesion to concrete, metal and other surfaces. The upper protective flashing layer laid on top of the flashing mastic makes a very strong, non-slip, resilient layer, resistant to UV, mechanical and chemical effects (Fig. 16).

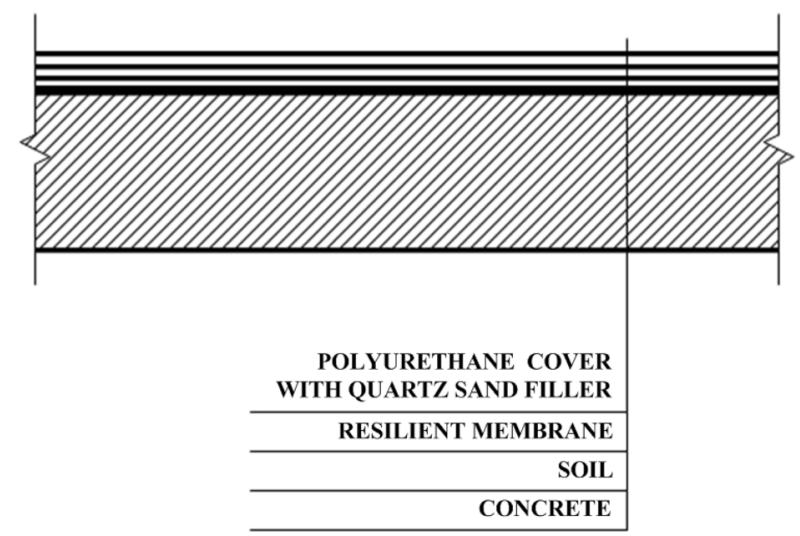

Fig. 16. The layers of car park area coverage in alternative $A_{1}$

Alternative $A_{2}$. Alternative technical solutions for solving problems of the car park installed on the exploitable roof are presented in Fig. 17. According to the research, water puddles appeared on the car park roof due to incorrect formation of floor slopes. The roof has been damaged by atmospheric and other effects (salt, mechanical damage caused by vehicle tires with studs, etc.), leaky roof drains have also been damaged. It is also recommended to solve problems related to structural deformations by installing waterproof, longitudinal and angular (connecting exploitable roof to the building) deformation seams, which should be selected in accordance with the appropriate parameters for construction deformation seams.

It is recommended to handle the problem of roof drain leakage at the sides only after examining their mounting technology. If the roof drains are technologically not properly equipped, it is proposed to replace them with new ones, designed specifically for exploitable roofs, or to renew the same drains in accordance with the appropriate technology.

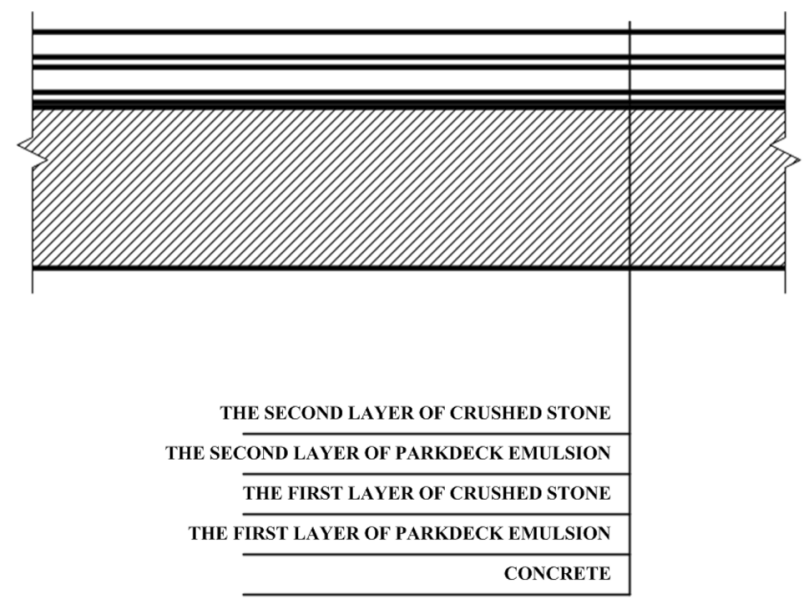

Fig. 17. The layers of car park area coverage in alternative $A_{2}$

\section{Selection of rational alternative for removal of roof defects and recovery of waterproofing layer}

In order to improve waterproofing installation technology of exploitable roofs, it was decided to carry out the comparison of acceptable variants and establish the most rational solution. Waterproofing layer recovery alternatives have been compared by applying multi attributes decision making methods COPRAS (Zavadskas, Kaklauskas 1996; Kaklauskas et al. 2006; Zavadskas et al. 2009), TOPSIS (Hwang, Yoon 1981) and SAW (MacCrimmon 1968). Multi attributes decision theory helps to make decisions on assessing several or more performance indicators that often conflict with each other. The researches with such conditions have performed Tupenaite et al. (2010), Zavadskas et al. (2010), Medineckiene et al. (2011), Kalibatas et al. (2011), Dejus (2011), Zolfani et al. (2011), Liu (2009) and others. With the help of multi attributes decision methods different problems can be solved, however all problems may have some common features, i.e. they may have several attributes, assessment criteria often contradict to each other, or assessment indicators have different units of measurement (Brauers, Zavadskas 2011; Brauers et al. 2010). Solving of these problems results in the creation of a rational alternative, or one alternative is chosen from a finite number of previously provided alternatives (Ustinovichius et al. 2009). As performance indicators contradict to each other, so a reasonable compromise need to be found (Antuchevičienè et al. 2010; Zavrl et al. 2009). Multi attributes decision methods let select a variant that best meets all the criteria.

The significances of performance indicators were determined by pair wise comparison method, i.e. by comparing pairs of indicators and determining "intensity of their importance to each other". In determining the prioritization the value scale, proposed by Saaty (1977) was used. Paired comparison method is convenient in the sense that experts can compare the performance indicators in pairs, which is important when comparing many indicators. Group assessment may be considered sufficiently reliable only when opinions of interviewed specialists are compatible. Therefore, when statistically processing information obtained from experts, compatibility of their opinions should be assessed and the reasons for ambiguity of the information should be identified. When applying the paired comparison method the degree of compatibility of each expert is determined by calculating the index and the ratio of compatibility. But this method does not verify the opinion compatibility of all experts, therefore it is proposed to apply the verification method of opinion compatibility (Ustinovichius et al. 2007).

After the questionnaire of experts are completed, a table in is formed and filled in with the mean values of indicators presented by the experts. With the help of experts a survey has been carried out, according to which the significance of specific performance indicators have been determined. The performance indicators for the evaluation of alternatives are:

$\mathrm{R} 1$ - price of repair of $1 \mathrm{~m}^{2}$ of waterproofing layer (Lt);

$\mathrm{R} 2$ - person-hours needed to repair $1 \mathrm{~m}^{2}$ of waterproofing layer (hours per person); 
Table 1. Initial decision making matrix

\begin{tabular}{l|c|c|c|c|c}
\hline \multirow{2}{*}{ Indicators } & \multirow{2}{*}{ Measuring units } & Optimality direction & \multirow{2}{*}{ Significance, $q_{i}$} & \multicolumn{2}{|c}{ Alternatives } \\
\cline { 3 - 6 } & & & $A_{1}$ & $A_{2}$ \\
\hline Price of $1 \mathrm{~m}^{2}$ repair & $\mathrm{Lt}^{*} / \mathrm{m}^{2}$ & $\min$ & 0.219 & 77 & 116 \\
\hline Person-hours & hours & $\min$ & 0.238 & 0.25 & 0.30 \\
\hline Repair duration & minutes & $\min$ & 0.011 & 7 \\
\hline Longevity & years & $\max$ & 0.389 & 7 & 5 \\
\hline Technological efficiency & points & $\max$ & 0.049 & 1.5 & 7 \\
\hline Slope after repair & $\%$ & $\min$ & 0.011 & 10 & 2.5 \\
\hline Aesthetic appearance & points & $\max$ & 3 \\
\hline
\end{tabular}

* a basic monetary unit of Lithuania, containing 100 cents, 1 EUR $=3.4528$ LTL

(the exchange rate fixed by Lithuanian central bank)

Table 2. The results of calculation applying COPRAS method

\begin{tabular}{|c|c|c|c|c|c|}
\hline \multirow{2}{*}{ Indicators } & \multirow{2}{*}{ Optimality direction } & \multirow{2}{*}{ Significance } & \multirow{2}{*}{ Measuring units } & \multicolumn{2}{|c|}{ Alternatives } \\
\hline & & & & $A_{1}$ & $A_{2}$ \\
\hline Price of repair & $\min$ & 0.219 & $\mathrm{Lt} / \mathrm{m}^{2}$ & 0.087 & 0.132 \\
\hline Person-hours & $\min$ & 0.238 & hours & 0.108 & 0.130 \\
\hline Repair duration & $\min$ & 0.011 & minutes & 0.008 & 0.003 \\
\hline Longevity & $\max$ & 0.389 & years & 0.227 & 0.162 \\
\hline Technological efficiency & $\max$ & 0.083 & points & 0.035 & 0.048 \\
\hline Slope after repair & $\min$ & 0.049 & $\%$ & 0.018 & 0.030 \\
\hline Aesthetic appearance & $\max$ & 0.011 & points & 0.008 & 0.002 \\
\hline \multicolumn{4}{|c|}{ Weighted sums of normalized maximizing criteria of the alternatives $S_{+j}$} & 0.269 & 0.213 \\
\hline \multicolumn{4}{|c|}{ Weighted sums of normalized minimizing criteria of the alternatives $S_{-j}$} & 0.222 & 0.295 \\
\hline \multicolumn{4}{|c|}{ Significances of the alternatives $Q_{j}$} & 0.565 & $\mathbf{0 . 4 3 5}$ \\
\hline \multicolumn{4}{|l|}{ Priorities of the alternatives } & 1 & 2 \\
\hline
\end{tabular}

$\mathrm{R} 3-1 \mathrm{~m}^{2}$ repair duration (in minutes);

R4 - longevity of performed repairs (years);

R5 - technological efficiency (points);

R6 - roof slope after repair (\%);

R7 - aesthetic appearance (points).

Alternatives with indicators' values and significances are presented in Table 1.

Table 2 presents calculations done by applying COPRAS method. The variants have also been compared by applying TOPSIS and SAW methods. Assessment results of analyzed alternatives $\left(A_{1}\right.$ and $\left.A_{2}\right)$ are presented in Table 3.

Table 3. Aggregated results of analyzed alternatives

\begin{tabular}{c|c|c}
\hline Method & $A_{1}$ & $A_{2}$ \\
\hline TOPSIS & $0.851(1)$ & $0.149(2)$ \\
\hline SAW & $0.970(1)$ & $0.749(2)$ \\
\hline COPRAS & $0.565(1)$ & $0.435(2)$ \\
\hline Rank & 1 & 2 \\
\hline
\end{tabular}

According to the values received in determining the rationality of alternatives, a conclusion follows that $A_{1}$ is a rational variant. Since the rationality of variants after application of the three methods totally coincides, we have not continued calculations with other methods provided in the methodology set MCDM for a case when variant rationalities do not coincide (Ustinovichius, Zavadskas 2004).

\section{Conclusions}

Lithuanian and foreign experience in roofing installation and requirements of Lithuanian legislation on of exploitable roofs has been analyzed. Analysis revealed the positive and negative features of flat roofs. In order to ensure the good performance of flat roofs it is suggested:

1. When designing flat roofs a special attention should be focused on the slopes of roof zone intersections. It is recommended to start designing the roof from the intersections and only then to select the slope for other zones of the future roof. This way would increase the reliability of design solutions. 
2. When installing flat roofs a strict control of work performance should be ensured. By analyzing the defects of the exploitable car park roofs it was found that typical non-conformities can be classified as non-compliance with construction requirements and violation of technological process requirements.

3. The analysis of case study object has been performed. Two alternatives for the reconstruction of waterproofing coating in order to ensure roof tightness have been offered. Multicriteria analysis of roof waterproofing alternatives has been carried out. It has been determined that the rational alternative for the removal of existing defects is $A_{1}$ alternative flooring system.

\section{References}

Antuchevičiené, J.; Zavadskas, E. K.; Zakarevičius, A. 2010. Multiple criteria construction management decisions considering relations between criteria, Technological and Economic Development of Economy 16(1): 109125. http://dx.doi.org/10.3846/tede.2010.07

Atkinson, A. R. 2002. The pathology of building defects; a human error approach, Engineering Construction and Architectural Management 9(1): 53-61.

Baskaran, A.; Molleti, S. 2009. Impact of air intrusion on the wind uplift performance of fully bonded roofing assemblies, Construction and Building Materials 23(2): 889901. http://dx.doi.org/10.1016/j.conbuildmat.2008.04.010

Baskaran, A.; Molleti, S.; Sexton, M. 2008. Wind performance evaluation of fully bonded roofing assemblies, Construction and Building Materials 22(3): 343-363. http://dx.doi.org/10.1016/j.conbuildmat.2006.08.011

Baskaran, B. A.; Ping, Ko, S. K.; Molleti, S. 2009. A novel approach to estimate the wind uplift resistance of roofing systems, Building and Environment 44(4): 723-735. http://dx.doi.org/10.1016/j.buildenv.2008.06.024

Brauers, W. K. M.; Zavadskas, E. K. 2011. Multimoora optimization used to decide on a bank loan to buy property, Technological and Economic Development of Economy 17(1): 174-188. http://dx.doi.org/10.3846/13928619.2011.560632

Brauers, W. K. M.; Ginevičius, R.; Podvezko, V. 2010. Regional development in Lithuania considering multiple objectives by the MOORA method, Technological and Economic Development of Economy 16(4): 613-640. http://dx.doi.org/10.3846/tede.2010.38

Dejus, T. 2011. Safety of technological projects using multicriteria decision making methods, Journal of Civil Engineering and Management 17(2): 177-183.

Fajkos, A. 2007. Temperature impact on sealed mutual overlap strength of bitumen sheets on roof structures, Revista Tecnologia da Universidade de Fortaleza 28(2): 222228.

Gajauskas, J. (Ed.). 2004. Construction Engineering Manual. Vilnius: Technika. 1096 p. (in Lithuanian)

Gränne, F.; Björk, F. 2000. Joints between roofing felt and sheet metal flashings - short- and long-term tests, Construction and Building Materials 14(6-7): 375-383.

Gränne, F.; Björk, F.; Noreng, K. 2003. Wind load resistance tests of heat-welded joints between roofing felt and sheet metal flashings, Construction and Building Materials 17(5): 319-324. http://dx.doi.org/10.1016/S0950-0618(03)00003-5
Hwang, C. L.; Yoon, K. S. 1981. Multiple Attribute Decision Making: Methods and Applications. Springer-Verlag, Berlin, Heidelberg, New York. 259 p. http://dx.doi.org/10.1007/978-3-642-48318-9

Ismail, A.; Samad, M. H. A.; Rahman, A. M. A. 2010. Potted plants on flat roof as a strategy to reduce indoor temperature in malaysian climate. American Journal of Engineering and Applied Sciences 3(3): 534-539. http://dx.doi.org/10.3844/ajeassp.2010.534.539

Kaklauskas, A.; Zavadskas, E. K.; Raslanas, S.; Ginevicius, R.; Komka, A.; Malinauskas, P. 2006. Selection of low-e windows in retrofit of public buildings by applying multiple criteria method COPRAS: A Lithuanian case, Energy and Buildings 38(5): 454-462. http://dx.doi.org/10.1016/j.enbuild.2005.08.005

Kalibatas, D.; Zavadskas, E. K.; Kalibatiene, D. 2011. The concept of the ideal indoor environment in multiattribute assessment of dwelling-houses, Archives of Civil and Mechanical Engineering 11(1): 89-101. http://dx.doi.org/10.1016/S1644-9665(12)60176-9

Karablikovas, A. 2007. Research on seams formation between the layers of glued bituminous roofing membranes and analysis of their parameters, Technological and Economic Development of Economy 13(2): 134-138.

Karablikovas, A.; Vilutienè, T. 2010. The research on gluing reliability of glued roller cover membranes, in 10th International Conference Modern Building Materials, Structures and Techniques: selected papers, 19-21 May, 2000, Vol. 1. Vilnius: Technika, 425-430.

Lisø, K. R.; Kvande, T.; Thue, J. V. 2005. High-performance weather-protective flashings, Building Research \& Information 33(1): 41-54. http://dx.doi.org/10.1080/0961321042000323798

Liu, P. 2009. Multi-attribute decision-making method research based on interval vague set and TOPSIS method, Technological and Economic Development of Economy 15(3): 453-463.

http://dx.doi.org/10.3846/1392-8619.2009.15.453-463

MacCrimmon, K. R. 1968. Decision making among multiple attribute alternatives: A survey and consolidated approach. RAND Memorandum, RM-4823-ARPA. 70 p.

Mailvaganam, N. P.; Collins, P. G. 1999. Effective installation of membranes on parking garage decks, Construction Technology Update 29: 1-4.

Mailvaganam, N. P.; Collins, P. G. 2004. Workmanship factors influencing quality of installed parking garage waterproofing membranes, Journal of Performance of Constructed Facilities ASCE 18(3): 121-126. http://dx.doi.org/10.1061/(ASCE)0887-3828(2004)18: $3(121)$

Medeliene, V.; Žiogas, V. A. 2010. Making solutions for choosing industrial concrete floors and expedience of reliability evaluation, Journal of Civil Engineering and Management $16(3)$ : 320-331. http://dx.doi.org/10.3846/jcem.2010.37

Medineckiene, M.; Zavadskas, E. K.; Turskis, Z. 2011. Dwelling selection by applying fuzzy game theory, Archives of Civil and Mechanical Engineering 11(3): 681-697. http://dx.doi.org/10.1016/S1644-9665(12)60109-5

Milosavljevic, N.; Simicevica, J.; Maletic, G. 2010. Vehicle parking standards as a support to sustainable transport system: Belgrade case study, Technological and Economic Development of Economy 16(3): 380-396. http://dx.doi.org/10.3846/tede.2010.24 
Nil, S.; Ertan, O. 2004. Proposed performance-based laboratory test method for measuring vapour and water permeability of waterproofing membranes under hydrostatic pressure, Construction and Building Materials 18(9): 701713. http://dx.doi.org/10.1016/j.conbuildmat.2004.03.015

Oba, K.; Hean, S.; Björk, F. 1996. Study on seam performance of polymer-modified bituminous roofing membranes using T-peel test and microscopy, Materials and Structures 29(2): 105-115.

http://dx.doi.org/10.1007/BF02486200

Oba, K.; Hugener, M. 1995. Characterization of polymer modified bituminous roofing membranes using chromatography, Materials and Structures 28(9): 534-544. http://dx.doi.org/10.1007/BF02473158

Ogle, R. A.; Megerle, M. V.; Morrison III, D. R.; Carpenter, A. R. 2004. Explosion caused by flashing liquid in a process vessel, Journal of Hazardous Materials 115(1-3): 133140. http://dx.doi.org/10.1016/j.jhazmat.2004.06.006

Rudbeck, C. 2002. Service life of building envelope components: making it operational in economical assessment, Construction and Building Materials 16(2): 83-89. http://dx.doi.org/10.1016/S0950-0618(02)00003-X

Saaty, T. L. 1977. A scaling method for priorities in hierarchical structures, Journal of Mathematical Psychology 15(3): 234-281.

http://dx.doi.org/10.1016/0022-2496(77) 90033-5

STR 1.05.06:2010 Static Design. Vilnius, 2010 (in Lithuanian).

STR 2.05.02:2008 Construction of buildings. Roofs. Vilnius, 2008 (in Lithuanian).

Tupenaite, L.; Zavadskas, E. K.; Kaklauskas, A.; Turskis, Z.; Seniut, M. 2010. Multiple criteria assessment of alternatives for built and human environment renovation, Journal of Civil Engineering and Management 16(2): 257266. http://dx.doi.org/10.3846/jcem.2010.30

Ustinovichius, L.; Barvidas, A.; Vishnevskaja, A.; Ashikhmin, I. V. 2009. Multicriteria verbal analysis for the decision of construction problems, Technological and Economic Development of Economy 15(2): 326-340. http://dx.doi.org/10.3846/1392-8619.2009.15.326-340

Ustinovichius, L.; Zavadskas, E. K.; Podvezko, V. 2007. Application of a quantitative multiple criteria decision making (MCDM-1) approach to the analysis of investments in construction, Control and Cybernetics 36(1): 251-268.
Ustinovičius, L.; Zavadskas, E. K. 2004. Statybos investiciju efektyvumo sistemotechninis ivertinimas [Multiple criteria assessment of investment profitability in construction]. Vilnius: Technika. 220 p. (in Lithuanian).

Vaitkus, S.; Laukaitis, A.; Gnipas, I.; Keršulis, V.; Vejjelis, S. 2006. Experimental analysis of structure and deformation mechanisms of expanded polystyrene (EPS) slabs, Materials Science (Medžiagotyra) 12(4): 323-327.

Walter, A.; de Brito, J.; Lopes, J. G. 2005. Current flat roof bituminous membranes waterproofing systems - inspection, diagnosis and pathology classification, Construction and Building Materials 19(3): 233-242. http://dx.doi.org/10.1016/j.conbuildmat.2004.05.008

Wong, N. H.; Tay, S. F.; Wong, R.; Ong, C. L.; Sia, A. 2003. Life cycle cost analysis of rooftop gardens in Singapore, Building and Environment 38(3): 499-509. http://dx.doi.org/10.1016/S0360-1323(02)00131-2

Zavadskas, E. K.; Kaklauskas, A. 1996. Pastatu sistemotechninis ivertinimas [Multiple criteria evaluation of buildings]. Vilnius: Technika. $280 \mathrm{p}$.

Zavadskas, E. K.; Kaklauskas, A.; Vilutiene, T. 2009. Multicriteria evaluation of apartment blocks maintenance contractors: Lithuanian case study, International Journal of Strategic Property Management 13(4): 319-338. http://dx.doi.org/10.3846/1648-715X.2009.13.319-338

Zavadskas, E. K.; Turskis, Z.; Vilutiene, T. 2010. Multiple criteria analysis of foundation instalment alternatives by applying Additive Ratio Assessment (ARAS) method, Archives of Civil and Mechanical Engineering 10(3): 123-141. http://dx.doi.org/10.1016/S1644-9665(12)60141-1

Zavrl, M. Š.; Žarnić, R.; Šelih, J. 2009. Multicriterial sustainability assessment of residential buildings, Technological and Economic Development of Economy 15(4): 612630. http://dx.doi.org/10.3846/1392-8619.2009.15.612-630

Zolfani, S. H.; Rezaeiniya, N; Zavadskas, E. K.; Turskis, Z. 2011. Forest roads locating based on AHP and COPRAS$G$ methods: an empirical study based on Iran, $E \& M$ : Ekonomie a Management 14(4): 6-21.

Leonas USTINOVICHIUS. Prof, Dr Habil, the chairman of the laboratory of Construction Technology and Management. Vilnius Gediminas Technical University. Dr (1989), Dr Habil (2002). Publications: more than 150 scientific papers. Research interests: building technology and management, decision-making theory, automation in design, expert systems.

Romas RASIULIS. PhD student in Department of Construction Technology and Management at Vilnius Gediminas Technical University. MSc degree (Building management and economics) Vilnius Gediminas Technical University (2002). Research interests: building technology and project management, decision-making theory, architectural design, expert systems.

Česlovas IGNATAVIČIUS. Doctor, Assoc. Prof. of Department of Construction Technology and Management at Vilnius Gediminas Technical University. Research interests: testing and determination of buildings' deterioration; modernization solutions; building energy audits; metering of quality of building indoor climate; metering of building energy consumption and parameters of heating insulation of external partitions; preparation of technological projects for renovation processes.

Tatjana VILUTIENE். Doctor, Assoc. Prof. in the Department of Construction Technology and Management at Vilnius Gediminas Technical University. Coordinator of EURO Working Group "OR in Sustainable Development and Civil Engineering“. Publications: more than 20 scientific papers. Research interests: decision-making in construction, project management in construction, facilities management and quality management in construction. 